\title{
Spontaneous and pokeweed mitogen induced production of rheumatoid factor and immunoglobulins in type II essential mixed cryoglobulinaemia
}

\author{
R A SINICO, ${ }^{1} \mathrm{G}$ FIORINI, ${ }^{2}$ A FORNASIERI, ${ }^{1}$ P BERNASCONI,
} S BENUZZI, ${ }^{1}$ M L PARACCHINI, ${ }^{2}$ AND G D'AMICO

From the ${ }^{1}$ Laboratory of Renal Immunopathology, Nephrology Department, and the ${ }^{2}$ Immunohaematology Department, San Carlo General Hospital, Milano, Italy

SUMMARY In order to evaluate functional lymphocyte defects in type II essential mixed cryoglobulinaemia (EMC) in vitro production of immunoglobulins (Ig) and rheumatoid factor (RF) has been studied in basal conditions and under pokeweed mitogen (PWM) stimulation in 15 patients and in 17 control subjects. The major finding was a significantly high basal and inducible production of RF by EMC lymphocytes as compared with the RF production in controls, while synthesis of polyclonal Ig was unaffected. A good correlation existed between in vitro production and serum levels of RF. Peripheral blood $\mathrm{SmIg}^{+}$and $\mathrm{Ia}^{+}$cells were also significantly increased. The possibility that EMC shares some pathogenetic mechanism with rheumatoid arthritis on the one hand and with lymphoproliferative diseases on the other is considered.

Key words: T lymphocyte subpopulations, immunoglobulin synthesis.

Type II EMC is a disease characterised by necrotising vasculitis with purpura, weakness, arthralgias, often glomerulonephritis, in the absence of underlying disorders. ${ }^{1-4}$

Immunochemical analysis of circulating cryoglobulins shows the presence of at least two immunoglobulins, a monoclonal Ig, usually IgM, with rheumatoid factor activity, which binds to the polyclonal IgG to form a cold insoluble immune complex. $^{2}$ Although a defect of the cell mediated immunity has been described in this disorder, ${ }^{5}{ }^{6}$ little is known about cellular mechanisms involved in the regulation of monoclonal cryo-RF production.

A spontaneous and inducible RF in vitro synthesis has been described in rheumatoid arthritis (RA), a closely related disease, ${ }^{7}$ but this RF is usually polyclonal and not cryoprecipitable.

These observations stimulated us to study the possibility that comparable alterations were present also in type II EMC, which is a peculiar autoimmune

Accepted for publication 17 January 1986.

Correspondence to $\operatorname{Dr} R$ A Sinico, Divisione di Nefrologia, Ospedale San Carlo Borromeo, Via Pio Secondo 3, 20153 Milano, Italy. disease, since the only detectable autoantibody (cryoprecipitable RF) is a monoclonal Ig. To do this we studied in vitro synthesis of Ig and RF in patients and controls, and evaluated possible alterations in lymphocyte subpopulations.

\section{Patients and methods}

PATIENTS

Fifteen patients (eight men and seven women) mean age 57 years (range 35-70), with mixed cryoglobulinaemia unassociated with any underlying disease were studied (Table 1). All had a history of purpura and arthralgias; 10 had diffuse proliferative glomerulonephritis proved by biopsy ${ }^{4}$ and seven hepatic involvement. Fourteen patients had IgG$\operatorname{IgM} x$ cryoglobulins, with trace amount of $\operatorname{IgA}$ in three; one had IgG-IgG $x$ cryoglobulins. No patient was receiving corticosteriods or immunosuppressive drugs, or both, at the time of the study nor in the previous eight weeks.

Seventeen normal subjects of comparable age and sex distribution formed the control group.

CRYOG L OB ULIN S

Isolation, purification, and immunochemical analy- 
Table 1 Main clinical and laboratory data

\begin{tabular}{|c|c|c|c|c|c|c|c|c|}
\hline $\begin{array}{l}\text { Patient } \\
\text { No }\end{array}$ & Age/sex & $\begin{array}{l}\text { Cryoglobulins } \\
\text { (cryocrit \%) }\end{array}$ & $\begin{array}{l}C 3^{*} \\
(\%)\end{array}$ & $\begin{array}{l}C 4^{*} \\
(\%)\end{array}$ & $\begin{array}{l}I g G^{*} \\
(m g / d l)\end{array}$ & $\begin{array}{l}\lg A^{*} \\
(m g / d l)\end{array}$ & $\begin{array}{l}\lg M^{*} \\
(m g / d l)\end{array}$ & $\begin{array}{l}\operatorname{IgM} R F^{*} \\
(\mu g / m l)\end{array}$ \\
\hline 1 & $35 / \mathrm{M}$ & $\begin{array}{l}\text { IgG-IgA-IgM } x \\
\text { (61) }\end{array}$ & 103 & 5 & 1070 & 263 & 261 & 226 \\
\hline 2 & $66 / F$ & $\begin{array}{l}\text { IgG-IgM } x \\
\text { (10) }\end{array}$ & 80 & 48 & 1310 & 419 & 339 & $35 \cdot 5$ \\
\hline 3 & $58 / \mathrm{M}$ & $\begin{array}{l}\text { IgG-IgMx } \\
\text { (40) }\end{array}$ & 57 & 5 & 700 & 144 & 208 & 285 \\
\hline 4 & $63 / \mathrm{F}$ & $\begin{array}{l}\text { IgG-IgM } x \\
\text { (4) }\end{array}$ & 65 & 42 & 1830 & 135 & 271 & 26 \\
\hline 5 & $59 / \mathrm{F}$ & $\begin{array}{l}\text { IgG-IgM } x \\
(22)\end{array}$ & 64 & 67 & 1430 & 77 & 217 & 15 \\
\hline 6 & $56 / \mathrm{F}$ & $\begin{array}{l}\text { IgG-IgA-IgM } x \\
\text { (32) }\end{array}$ & 40 & 5 & 1130 & 220 & 339 & 12 \\
\hline 7 & $60 / F$ & $\begin{array}{l}\text { IgG-IgM } x \\
(26)\end{array}$ & 69 & 5 & 963 & 144 & 414 & 20 \\
\hline 8 & $53 / \mathrm{M}$ & $\begin{array}{l}\text { IgG-IgM } x \\
\text { (14) }\end{array}$ & 69 & 20 & 1190 & 135 & 123 & $37 \cdot 2$ \\
\hline 9 & $70 / \mathrm{M}$ & $\begin{array}{l}\text { IgG-IgMx } \\
\text { (12) }\end{array}$ & 87 & 5 & 1190 & 118 & 840 & 476 \\
\hline 10 & $52 / \mathrm{M}$ & $\begin{array}{l}\text { IgG-IgM } x \\
\text { (5) }\end{array}$ & 75 & 5 & 1370 & 42 & 280 & $7 \cdot 8$ \\
\hline 11 & $64 / F$ & $\begin{array}{l}\text { IgG-IgM } x \\
\text { (1) }\end{array}$ & 130 & 5 & 1230 & 347 & 212 & 34 \\
\hline 12 & 44/M & $\begin{array}{l}\text { IgG-IgM } x \\
(90)\end{array}$ & 69 & 20 & 1560 & 135 & 1595 & $5 \cdot 3$ \\
\hline 13 & $63 / \mathrm{M}$ & $\begin{array}{l}\text { IgG-IgA-IgM } x \\
\text { (30) }\end{array}$ & 70 & 25 & 1120 & 320 & 650 & 50 \\
\hline 14 & $52 / \mathrm{F}$ & $\begin{array}{l}\operatorname{IgG}-\operatorname{IgM} x \\
\text { (2) }\end{array}$ & 97 & 58 & 1080 & 82 & 190 & 13 \\
\hline 15 & $66 / M$ & $\begin{array}{l}\text { IgG-IgGx } \\
\text { (16) }\end{array}$ & 33 & 5 & 1690 & 543 & 234 & 2 \\
\hline
\end{tabular}

${ }^{*}$ Normal values: C3 65-140\%; C4 43-146\%; IgG $800-1800 \mathrm{mg} / \mathrm{dl} ; \operatorname{IgA} 90-450 \mathrm{mg} / \mathrm{dl}$; IgM 70-280 mg/dl; IgM $\mathrm{RF}<8 \mu \mathrm{gg} / \mathrm{ml}$. SI conversion: $\mathrm{mg} / \mathrm{dl} \times 0 \cdot 01=\mathrm{g} / \mathrm{l}$.

sis of cryoglobulins were performed as previously described. $^{8}$

SERUM IMMUNOGLOBULINS

Serum Igs were determined by radial immunodiffusion using commercially available plates (Behringwerke).

COMPLEMEN T

C3 and C4 were measured quantitatively with commercially available immunodiffusion plates (Behringwerke). Results were expressed as the percentage of pooled normal human serum.

CELL S EPARATION

Mononuclear cells were obtained from peripheral blood by centrifugation on a gradient of FicollHypaque (Biotest Laboratories). The cells thus obtained were washed three times in sterile phosphate buffered saline before further processing.

LYMPHOCYTE MEMBRANE MARKERS

A panel of monoclonal antibodies (Ortho $\mathrm{Ph}$ Corp) was used to identify $\mathrm{T}$ cell subsets and $\mathrm{Ia}^{+}$cells. $\mathrm{B}$ lymphocytes were identified with a fluorescein isothiocyanate labelled $\mathrm{F}(\mathrm{ab}) 2$ goat antihuman $\mathrm{Ig} \stackrel{\mathrm{O}}{\frac{\mathrm{O}}{2}}$ antiserum (Meloy Labs). Indirect and direct im- $-\frac{5}{\circ}$ munofluorescence techniques were used as described $\exists$. elsewhere. ${ }^{9} 10$

CULTURE CONDITIONS

Cells were cultured at a concentration of $10^{6} / \mathrm{ml}\left(10^{9} / \mathrm{l}\right)$ in complete medium (RPMI $1640+10 \%$ fetal calf serum $+2 \mathrm{mM}$ L-glutamine; all reagents from Flow Laboratories) without antibiotics. The cultures were $\widehat{N}$ run in duplicate; one set in basal conditions, the $N$ other stimulated with $20 \mu \mathrm{g} / \mathrm{ml}$ PWM (Flow). The N cultures were kept in a humidified atmosphere at ${ }_{\sigma}^{\omega}$ $37^{\circ} \mathrm{C}$ with $5 \% \mathrm{CO}_{2}$ for seven days. On the eighth day they were collected and centrifuged at $2000 \mathrm{rpm}$ for 15 minutes. The supernatants were then deep@ frozen, and the pelleted cells were discarded.

I M M U NOGLOBULIN ASSAY An enzyme linked immunosorbent assay (ELISA) ${ }^{11}$ was used, according to the method of Rodriguez et $\varrho$ $a l,{ }^{12}$ with minor modifications. Briefly, standards and 
samples were incubated in microtitre plates (Dynatech) coated with anti-Ig class specific antibodies. After three washes with phosphate buffered saline containing $0.05 \%$ Tween 20 a class specific alkaline phosphatase conjugated antibody (Sigma) was added, and the plates were then incubated at $37^{\circ} \mathrm{C}$ for one hour. After three more washes the enzyme substrate (Sigma) was added, and the plates were read in a Titertek Multiskan MC photometer (Flow). The optical density values were converted to $\mathrm{ng} / \mathrm{ml}$ by plotting against suitable reference curves.

Table $2 T$ and $B$ cell membrane markers (percentage of positive cells), and T4/T8 ratio in the patients studied and in the control population

\begin{tabular}{lccl}
\hline & Patients & Controls & $p$ \\
\hline OKT4 & $46 \cdot 2 \pm 9 \cdot 2^{*}$ & $49 \cdot 4 \pm 7 \cdot 9$ & - \\
OKT8 & $36 \cdot 6 \pm 10 \cdot 1$ & $30 \cdot 4 \pm 7 \cdot 3$ & - \\
OKIa & $12 \cdot 3 \pm 7 \cdot 8$ & $3 \cdot 7 \pm 2 \cdot 1$ & $<0 \cdot 001$ \\
SmIg & $13 \cdot 1 \pm 7 \cdot 2$ & $7 \cdot 7 \pm 3 \cdot 0$ & $<0 \cdot 02$ \\
T4/T8 & $1 \cdot 4 \pm 0 \cdot 8$ & $1 \cdot 6 \pm 0 \cdot 4$ & - \\
\hline
\end{tabular}

*Values are mean \pm SD.
ENZYME LINKED IMMUNOSORBENT ASSAY (ELISA) FOR IgM RF

Levels of IgM RF in the sera and supernatants of both unstimulated and PWM stimulated cultures were determined by an ELISA as previously described. ${ }^{8}$

\section{Results}

Table 2 shows the relative percentages of $\mathrm{T}$ cell subpopulations and B cells in patients and controls. Since the mean lymphocyte count did not differ significantly between the two groups the numbers shown also reflect changes in absolute values, the main finding being an increase in activated $B$ lymphocytes $\left(\mathrm{SmIg}^{+}, \mathrm{Ia}^{+}\right.$cells).

No significant differences were noticed between patients and controls as far as Ig synthesis was concerned. This applied to both spontaneous and PWM induced production (Table 3). This finding was further supported by the observation that the serum Ig levels were not significantly different in patients and controls (see Table 1) even though three patients had IgM levels much higher than the normal range. In spite of this, patients' B lymphocytes produced large

Table 3 Spontaneous $\left(P W M^{-}\right)$and $P W M$ induced $\left(P W M^{+}\right)$Ig synthesis by peripheral blood lymphocytes from patients and controls

\begin{tabular}{|c|c|c|c|c|}
\hline & \multicolumn{2}{|l|}{ Patients } & \multicolumn{2}{|l|}{ Controls } \\
\hline & $P W M^{+}$ & $P W M^{-}$ & $P W M^{+}$ & $P W M^{-}$ \\
\hline $\begin{array}{l}\text { IgG (ng/ml) } \\
\text { IgA (ng/ml) } \\
\text { IgM (ng/ml) }\end{array}$ & $\begin{array}{l}7086 \pm 1692^{*} \\
3483 \pm 1357 \\
1987 \pm 971\end{array}$ & $\begin{array}{r}1099 \pm 300 \\
458 \pm 115 \\
384 \pm 199\end{array}$ & $\begin{array}{l}5138 \pm 1351 \\
2682 \pm 643 \\
1373 \pm 508\end{array}$ & $\begin{array}{l}603 \pm 104 \\
650 \pm 215 \\
144 \pm 71\end{array}$ \\
\hline
\end{tabular}

*Values are mean \pm SEM.

SI conversion: $\mathrm{ng} / \mathrm{ml} \times 10^{-6}=\mathrm{g} / \mathrm{l}$.

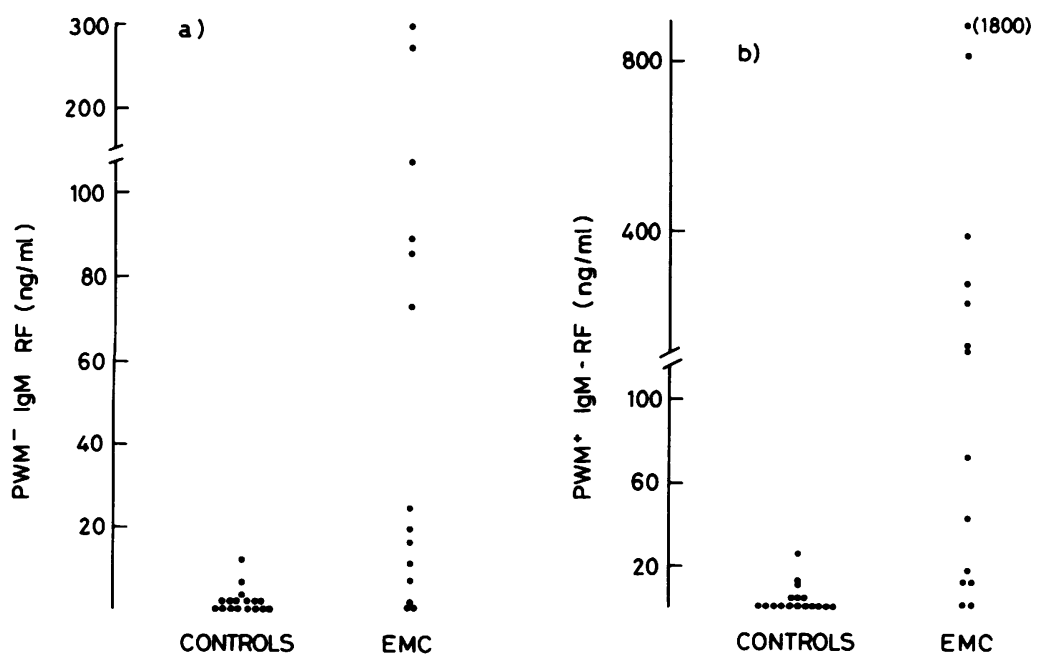

Fig. 1 Spontaneous (a) and $P W M$ induced (b) IgM RF synthesis by peripheral blood lymphocytes from patients and controls. 
amounts of IgM RF, which was not the case with the cells of control subjects $\left(\mathrm{PWM}^{-}\right.$: mean \pm SEM $77.8 \pm 34.6 v 1.2 \pm 0 \cdot 8 \mathrm{ng} / \mathrm{ml}, \mathrm{p}<0.02 ; \mathrm{PWM}^{+}: 286 \cdot 1 \pm$ $141.7 v 3.1 \pm 1.8 \mathrm{ng} / \mathrm{ml}, \mathrm{p}<0.05)$ (Fig. 1). In particular, 10 out of 14 patients $(71 \%)$ produced amounts of IgM $\mathrm{RF}$ greater than the normal range, calculated as the mean $\pm 2 S D$ of the controls. Interestingly a good correlation existed between the amount of RF produced in vitro and serum RF levels $(p<0.01$ for basal production; $\mathrm{p}<0.05$ for $\mathrm{PWM}$ induced production). On the other hand, no correlation was found with other clinical features.

\section{Discussion}

To our knowledge this is the first study of in vitro production of RF by peripheral blood lymphocytes from patients with type II EMC. This has been done extensively in RA, a closely related disorder, where an increased production has been described by many workers. ${ }^{7}{ }^{12}{ }^{13}$ Such an increased production has been found in our patients as well and, interestingly, it was not associated with other significant disturbances in Ig production. A good correlation existed between serum IgM RF and in vitro production of $\mathrm{RF}$, as described for RA patients. ${ }^{12}{ }^{13}$ Moreover, no major changes were found in peripheral blood lymphocytes except for a marked increase in activated B cells.

These data suggest an expansion of B cells committed to IgM RF production. Whether this is a primary event or, as suggested by others, ${ }^{514}$ a result of an impaired $T$ cell regulation, cannot be decided on the basis of our findings. It is, however, interesting to notice that since $T$ cell subsets appeared to be in the normal range an intrinsic $B$ cell defect seems to be more likely, even if a functional $T$ cell defect cannot be ruled out in the presence of normal $\mathrm{T}$ lymphocyte subsets.

Moreover, the coexistence of a B and $\mathrm{T}$ helper defect has been reported in type III EMC to explain a reduced in vitro Ig synthesis. ${ }^{15}$ On the basis of our results we can only speculate on the nature of the RF which is synthesised; it has been recently shown, however, that PWM induced blasts from the peripheral blood of EMC patients, and bone marrow B cells, express the same cross reactive idiotype of circulating RF. ${ }^{16}{ }^{17}$ It should also be noted that, as described for $\mathrm{RA}^{7}{ }^{7}$ some of our patients did not produce IgM RF, the only distinguishing feature of these subjects being the low amount of circulating RF. When cryoglobulinaemic lymphocytes were stimulated with PWM they responded by secreting increased levels of RF (from $77 \cdot 8 \pm 34.6$ to $286 \cdot 1 \pm 141 \cdot 7 \mathrm{ng} / \mathrm{ml}$ ), but the IgM RF/IgM ratio was lower than in unstimulated cultures, suggesting the presence of B lymphocytes committed to in vivo IgM
RF production. These could hardly be influenced by a polyclonal activator in vitro. Our results seem to $\frac{0}{\text { s. }}$ indicate that type II EMC should be considered related in some way to lymphoproliferative disorders, $\stackrel{\vec{\rho}}{\stackrel{9}{\rho}}$ as already suggested by the development of such 을 diseases in patients with $\mathrm{EMC}^{3}{ }^{18}$ and by the high incidence of secondary cryoglobulinaemias in such $\frac{5}{\partial}$ malignancies. ${ }^{212}$ Normal in vitro polyclonal $\operatorname{Ig} \stackrel{\varnothing}{\complement}$ production appears to be maintained in EMC, as also $\&$ suggested by normal Ig serum levels. This is frequently $\overrightarrow{0}$ not the case in lymphoid neoplasms (unpublished data). ${ }^{19} 20$

\section{References}

1 Meltzer M, Franklin E C, Elias K, McCluskey R T, Cooper N ثै Cryoglobulinemia - a clinical and laboratory study. Am J Med $V$ 1966; 40: 837-56.

2 Brouet J C, Clauvel J P, Danon F, Klein M, Seligmann M. Biologic and clinical significance of cryoglobulins. Am J Med 음 1974; 57: 775-88.

3 Gorevic P D, Kassab H J, Levo Y, et al. Mixed cryoglobulinemia: clinical aspects and long-term follow-up of 40 patients. Am J Med 1980; 69: 287-308.

4 D'Amico G, Ferrario F, Colasanti G, Bucci A. Glomeru- $\vec{\omega}$ lonephritis in essential mixed cryoglobulinaemia. In: Davison A M, Guillon PJ, eds. Proceedings EDTA-ERA. London: Pitman Books 1984; 21: 527-48.

5 Meroni P L, Barcellini W, Messina C, De Bartolo G, Capsoni F, Invernizzi $F$. Defective suppressor cell activity in essential mixed cryoglobulinemia. J Clin Lab Immunol 1982; 8: 177-82.

6 Pietra A, Paracchini M L. Gibelli A, et al. Increased monocyte procoagulant activity (tissue factor) in patients with essential mixed cryoglobulinemia. Am J Clin Pathol (in press).

7 Tsoukas C D, Carson D A, Fong S, Pasquali J L, Vaughan J H. Cellular requirements for pokeweed mitogen-induced auto- $\exists$ antibody production in rheumatoid arthritis. $J$ Immunol 1980; 125: $1125-9$.

8 Fiorini G, Bernasconi P. Sinico R A, Chianese R, Pozzi F, D'Amico G. Increased frequency of antibodies to ubiquitous viruses in essential mixed cryoglobulinaemia. Clin Exp Immunol (in press).

9 Fornasieri A, Sinico R, Fiorini G, et al. T-lymphocyte subsets in primary and secondary glomerulonephritis. In: Davison A M, ̊ Guillon P J, eds. Proceedings EDTA. London, Pitman Books, 1980: 635-41.

10 Fornasieri A. Sinico R A, Goldaniga D, Fiorini G F, Colasanti G, 을 D'Amico G. B-lymphocyte subpopulations and T-cell subsets in $D$ primary chronic glomerulonephritis. Clin Nephrol 1983; 20:음 267-8.

11 Anonymous. ELISA: a replacement for radioimmunoassay? $\mathrm{N}$ [Editorial]. Lancet 1976; ii: 406-7.

12 Rodriguez M A, Bankhurst A D, Williams R C Jr, Troup G M, $N$ Stastny P. Studies on the relationship between HLA DR4 and in N vitro IgM rheumatoid factor production. Clin Immunol Im-
munopathol 1983; 27: 96-109.

13 Carson D A, Pasquali J L, Tsoukas C D, et al. Physiology ande pathology of rheumatoid factors. Springer Semin Immunopathol 1981; 4: 161-79.

14 Meroni P L, Ciboddo G F, Colombo G, Bonara P, Invernizzi F.? $T$ cell defect in essential mixed cryoglobulinaemia. Int Arch Allergy Appl Immunol 1979; 59: 308-14.

15 Meroni P L, Barcellini W, De Bartolo G, Invernizzi F, Zanussi C. Abnormalities of in vitro immunoglobulin synthesis by peripheral $\frac{\overrightarrow{\mathbb{D}}}{\mathrm{Q}}$ blood lymphocytes from patients with essential mixed cryoglo- $\varrho$ bulinaemia. Clin Immunol Immunopathol 1984; 33: 245-57. 
16 Bonagura V R, Kunkel H G, Pernis B. Cellular localization of rheumatoid factor idiotypes. J Clin Invest 1982; 69: 1356-65.

17 Gharavi A E, Patel B M, Hughes G R V, Elkon K B. Common IgA and IgM rheumatoid factor idiotypes in autoimmune diseases. Ann Rheum Dis 1985; 44: 155-8.

18 Invernizzi F, Galli M, Serino G, et al. Secondary and essential cryoglobulinemias. Acta Haematol (Basel) 1983; 70: 73-82.
19 Peest D, Brunkhorst U, Schedel I, Deicher H. In vitro immunoglobulin production by peripheral blood mononuclear cells from multiple myeloma patients and patients with benign monoclonal gammopathy. Regulation by cell subsets. Scand J Immunol 1984; 19: 149-57.

20 Sacchi N, LeBien T V, Trost S, Breviario D, Bollum F J. Phorbol ester-induced changes in human leukemic pre-B lines. Cell Immunol 1984; 84: 65-73. 